\title{
OPTIMALISASI SUMBER DAYA MANUSIA KEPOLISIAN REPUBLIK INDONESIA DALAM PENINGKATAN PELAUANAN PUBLIK DI KEPOLISIAN RESOR GRESIK
}

\author{
Erieg Adi Cahyono \\ erieg.gresik@gmail.com \\ Kantor Bupati Gresik \\ Jl. Dr. Wahidin Sudirohusodo No. 245, \\ Kembangan, Gresik Regency
}

\begin{abstract}
Police function in the state government system in the presence of police institutions is indispensable to the community. No community does not have a police institution. Police are tasked with maintaining the security and public Order (Kamtibmas). In addition, police also acted as law enforcement officers. Police are part of the criminal justice system along with other law enforcement officers, namely prosecutors and courts. The important role of human resources of Gresik in improving public services is very important to improve the quality that is in accordance with the expectations of the community and implemented in a unified network that is simple, open , smooth, precise, complete, reasonable, and affordable in accordance with the principles of public service.
\end{abstract}

Keywords: Police, Human Resources and Public Services.

\begin{abstract}
Abstrak
Fungsi Kepolisian dalam sistem Pemerintahan Negara keberadaan lembaga kepolisian sangat diperlukan oleh masyarakat. Tiada satupun masyarakat yang tidak mempunyai institusi kepolisian. Polisi bertugas memelihara keamanan dan ketertiban masyarakat (Kamtibmas). Di samping itu, polisi juga berperan sebagai aparat penegak hukum. Polisi merupakan bagian dari criminal justice system bersama aparat penegak hukum yang lain, yaitu kejaksaan dan pengadilan. peran penting sumberdaya manusia Polres Gresik dalam meningkatkan pelayanan publik sangatlah penting guna meningkatkan kualitas yang sesuai dengan yang diharapkan masyarakat serta dilaksanakan dalam suatu rangkaian terpadu yang bersifat sederhana, terbuka, lancar, tepat, lengkap, wajar, dan terjangkau sesuai asas-asas pelayanan publik.
\end{abstract}

Kata Kunci: Polisi, Sumber daya manusia dan Pelayanan publik. 


\section{A. Pendahuluan}

Polisi adalah publik, Publik adalah polisi sebagaimana pernah ditulis oleh Sir Robert Peel dalam bukunya Apolitical and Social History yang intinya "The Police are the public and the public are the police; the police being only members of the public who are paid to give full time attention to duties which are incumbent on every citizen in the intetest of community welfare and existence"Polisi adalah anggota masyarakat yang digaji untuk menjalankan tugasnya secara penuh waktu tetapi masyarakat juga memiliki tanggungjawab yang sama sehingga semua anggota kepolisian tidak bias terlepas dari kehidupan bermasyarakat. ${ }^{1}$

Polri sebagai sub sistem dari pemerintah secara responsif telah berupaya memberi kontribusi mewujudkan prinsip Good Governance dan Clean Government baik dalam pelaksanaan tugas pokok memelihara Kamtibmas, menegakkan hukum dan melindungi, mengayomi serta melayani masyarakat maupun di kalangan internal Polri sendiri sebagaimana dicanangkan dalam grand strategi Polri berupa Trust Building (membangun kepercayaan). ${ }^{2}$

Kompleksitas tantangan tugas Polri pada era reformasi dalam perjalanannya selain telah memberi manfaat bagi Polri dengan berbagai kemajuan yang signifikan baik di bidang pembangunan kekuatan, pembinaan maupun operasional. Namun di sisi lain diakui secara jujur terdapat akses negatif dari penyelenggaraan tugas pokoknya berupa penyimpangan perilaku anggota Polri seperti penyalahgunaan kekuasaan / wewenang (abuse of power), dan melakukan perbuatan tercela lainnya yang melangggar kaidah-kaidah moral, social dan keagamaan.

Data statistik yang dimiliki dan dirilis oleh polda Jatim tahun 2018 menunjukkan adanya 413 pengaduan masyarakat terkait institusi Kepolisian dengan berbagai permasalahan diantaranya pelayanan buruk, penyalahgunaan kewenangan, kekeliruan deskresi, dekriminasi dan korupsi masih menjadi angka tertinggi dalam pelanggaran yang dilakukan oleh personel Polri sedangkan upaya penanganan pengaduan masyarakat tersebut telah dilaksanakan tindakan kepada anggota yang melanggar berupa putusan teguran tertulis, penundaan kenaikan pangkat, penundaan pendidikan, mutasi bersifat demosi, penundaan gaji berkala dan penempatan khusus ${ }^{3}$

Upaya mewujudkan perbaikan citra polri telah banyak dilakukan institusi dibawahnya tidak terkecuali yang dilakukan oleh polres Gresik dengan membentuk beberapa kebijakan pelayanan yang berbasis teknologi informasi

\footnotetext{
${ }^{11}$ Karnavian, Muhammad Tito. (2017). Democratic Policing. Jakarta.

${ }^{2}$ Grand Strategi Polri 2005-2025.

${ }^{3}$ Laporan Tahunan Bidang Profesi dan Pengamanan Kepolisian Daerah Jawa Timur tahun 2018
} 
dan keterbukaan serta mengedepankan hubungan secara langsung (tatap muka) antara petugas kepolisian dengan masyarakat sehingga diharapkan masyarakat tidak lagi merasa sulit dan canggung dalam berkomunikasi dengan aparat kepolisian baik dalam menyampaikan kritik maupun saran untuk sedikit demi sedikit memberikan kepercayaan dan citra baik ke institusi Kepolisian ${ }^{4}$.

Polres Gresik dalam upaya membangun citra baik dimasyarakat terkait pelayanan telah melaksanakan program inovasi pelayanan publik dengan meluncurkan program "Gajah Mada" (Gerakan antisipasi kejahatan dan pemecahan masalah masyarakat Desa) dengan sistem membentuk tim khusus yang beranggotakan anggota Kepolisian,TNI dan ASN yang telah mendapatkan pembekalan khusus sebelum melaksanakan tugas untuk terjun ke masyarakat melalui silaturahmi dari rumah ke rumah sebagai upaya falisitasi dan penggalian informasi dari masyarakat sebagai upaya perbaikan citra Polri di masyarakat serta mempermudah akses pengaduan masyarakat melalui sosialisasi tata cara pelaporan, yang selama ini diatur dalam Peraturan Kepolisian Nomor 9 Tahun 2018 tentang Tata Cara Penanganan Pengaduan Masyarakat Di Lingkungan Kepolisian Negara Republik Indonesia. Jumlah laporan yang diterima oleh Polres Gresik tentang pengaduan masyarakat terkait institusi Kepolisian memiliki makna bermacam macam, semakin banyak laporan masyarakat dapat dimaknai menurunnya angka pelayanan Polri namun dapat diartikan juga bahwa masyarakat merasa percaya sehingga tidak segan melaporkan ketidakwajaran yang terjadi pada institusi polri begitu juga sebaliknya semakin sedikit laporan pengaduan masyarakat terhadap institusi Polri bukan berarti semakin baik kinerja pelayanan Polri kepada masyarakat namun juga perlu didalami apakah memang benar benar masyarakat telah puas sehingga tidak ada pengaduan atau masyarakat enggan melaporkan karena tingkat kepercayaan yang kurang atau bahkan tidak mengetahui tata cara melaporkan apabila terjadi ketidakwajaran dalam pelayanan yang dilakukan oleh institusi Polri.

\section{B. Pembahasan}

Hukum bukan merupakan ilmu pasti yang dapat dipastikan secara mutlak. Tidak ada kepastian mutlak mengenai pengertian hukum. Banyaknya para ahli hukum mendefinisikan hukum secara berbeda-beda. Hukum berlangsung selama ribuan tahun, dan merupakan warisna paling berharga dari peradaban barat. Pendekatan terhadap hukum tidak dapat didefinisikan secara tepat. Menurut Friedman, bahwa hukum berada di awing-awang, tidak tampak dan tidak terasa bahkan biasanya selembut udara dalam sentuhan normal (law is in atmosphere, invisible and unfeltoften as light as air to the normal touch). ${ }^{5}$

\footnotetext{
${ }^{4}$ Yudiswan, Adex. (2016). Gerakan Antisipasi Kejahatan dan Pemecahan Masalah Masyarakat Desa (Gajah Mada).Gresik: Rayhan Intermedia.

${ }^{5}$ Ali, Achmad. (2012). Menguak Teori Hukum (Legal Theory) dan Teori Peradilan Republik Indonesia. Jakarta: Sinar Grafika, p.28.
} 
Hukum tidak hanya dapat berubah (berbeda) dalam ruang melainkan juga dalam waktu, ini berlaku baik untuk sumber-sumber hukum formal yakni bentuk- bentuk penampilan dari kaidahkaidah hukum maupun bentuk hukum tersebut. Sumber hukum pada umumnya adalah segala sesuatu yang dapat menimbulkan aturan hukum serta tempat diketemukannya aturan hukum. Sumber hukum bisa dilihat dari faktor -faktor yang mempengaruhinya atau dilihat dari bentuknya. Sumber hukum yaitu sumber hukum materiil dan formil. Sumber hukum materil meliputi faktor-faktor yang ikut mempengaruhi materi (isi) dari aturan-aturan hukum, sedangkan sumber hukum formil adalah berbagai bentuk aturan hukum yang ada.

Sumber hukum formal adalah sumber dengan bentuk tertentu yang merupakan dasar berlakunya hukum secara formal. Sumber hukum formal merupakan dasar kekuatan mengikat peraturan-peraturan agar ditaati masyarakat maupun penegak hukum. Sumber hukum formal antara lain :

1. Undang-Undang adalah peraturan negara yang dibentuk oleh alat perlengkapan negara yang berwenang dan mengikat masyarakat.

2. Kebiasaan adalah perbuatan manusia mengenai hal tertentu yang dilakukan secara berulangulang dan terhadapnya dipertalikan adanya ide hukum, sehingga perbuatan tersebut diterima dan dilakukan oleh suatu masyarakat.

3. Yurisprudensi adalah keputusan pengadilan atau keputusan hakim yang terdahulu, yang dianggap tepat sehingga diikuti oleh pengadilan atau hakim lain.

4. Traktat (perjanjian antar negara) adalah perjanjian antar Negara yang telah disahkan berlaku mengikat Negara peserta, termasuk warga negaranya.

5. Doktrin adalah pendapat para sarjana hukum terkemuka yang besar pengaruhnya terhadap perkembangan hukum pada umumnya dan secara khusus terhadap hakim dalam mengambil keputusannya. $^{6}$

Definisi umum dari hukum adalah perangkat asas dan kaidah-kaidah yang mengatur hubungan antara manusia dalam masyarakat, baik yang merupakan kekerabatan, kampung atau desa, atau suatu Negara yang dengan demikian masyarakat mengatur kehidupannya menurut nilai-nilai yang sama-sama mereka anut, karena mempunyai tujuan tertentu. Hukum merupakan suatu sistem atau tatanan asas-asas dan kaidah-kaidah hokum yang tidak lepas dari masalah keadilan, maka definisi hukum positif yang lengkap adalah sistem atau tatanan hukum dan asas-asas berdasarkan keadilan yang mengatur kehidupan manusia di dalam masyarakat. ${ }^{7}$

\footnotetext{
${ }^{6}$ Sudaryanto, Agus. (2015). Pengantar Ilmu Hukum. Malang: Setara Press. p. 89-99.

${ }^{7}$ Kusumaatmadja, Mochtar dan Sidharta , Bernard Arief.( 2004). Pengantar Ilmu Hukum. Buku I. Bandung: Alumni..p.5.
} 
Hukum adalah norma yang mengajak masyarakat untuk mencapai cita-cita serta keadaan tertentu tanpa mengabaikan dunia kenyataan oleh karenanya digolongkan kedalam norma kultur yang memperlihatkan cirri-ciri dari suatu norma yang digolongkan kedalam norma susila yang menunjukkan apa yang seharusnya dilakukan, bukan apa yang pasti akan dilakukan. ${ }^{8}$ Menurut $\mathbf{O}$. Notohamidjojo, mengenai pengertian hukum bahwa keseluruhan peraturan yang tertulis dan tidak tertulis yang biasanya bersifat memaksa untuk kelakuan manusia dalam masyarakat Negara serta antarnegara yang berorientasi pada (sekurang-kurangnya) dua asas yaitu keadilan dan daya guna, demi tata dan damai dalam masyarakat.

Menurut Simanjuntak, Pengaduan adalah pernyataan ketidakpuasan apapun bentuknya (tertulis, lisan maupun melalui bahasa tubuh) tentang pelayanan, tindakan dan/ atau kekurangan tindakan yang`dilakukan oleh instansi penyelia pelayanan atau para stafnya yang mempengaruhi dan dirasakan oleh pengguna pelayanan tersebut. ${ }^{9}$ Berdasarkan ketentuan Pasal 1 angka 25 KUHAP, pengaduan adalah pemberitahuan disertai permintaan oleh pihak yang berkepentingan kepada pejabat yang berwenang untuk menindak menurut hukum seorang yang telah melakukan tindak pidana aduan yang merugikannya. Berdasarkan Peraturan Presiden Nomor 76 Tahun 2013 tentang Pengelolaan Pengaduan Pelayanan Publik, pengaduan adalah penyampaian keluhan yang disampaikan pengadu kepada pengelola pengaduan pelayanan publik atas pelayanan pelaksana yang tidak sesuai dengan standar pelayanan, atau pengabaian kewajiban dan/ atau pelanggaran larangan oleh penyelenggara.

Pada prinsipnya pelayanan pengaduan masyarakat kepada pemerintah diupayakan agar mempermudah masyarakat yang akan menyampaikan pengaduannya, antara lain dengan menyediakan layanan hotline, faksimili dan situs web sebagai sarana mempermudah pengaduan masyarakat. Secara garis besar, pengaduan masyarakat yang diterima langsung oleh Pemerintah diteruskan kepada masing-masing APIP untuk mendapatkan petunjuk/arahan lebih lanjut. Pengaduan dimaksud umumnya dapat dibedakan, sebagai berikut :

1. Pengaduan yang berkaitan dengan penyimpangan dan/atau penyalahgunaan wewenang yang dilakukan pejabat/pegawai unit eselon I di lingkungan Depkeu. Jika isi pengaduan dianggap “material”, maka penanganan lebih lanjut dilakukan oleh IBI.

2. Pengaduan yang tidak berkaitan dengan penyimpangan dan/atau penyalahgunaan wewenang, yang terdiri dari :

\footnotetext{
${ }^{8}$ Satjipto Rahardjo.( 2012). Ilmu Hukum. Bandung: Citra Aditya Bakti.p.25.

${ }^{9}$ Lembaga Administrasi Negara.Op.Cit.
} 
1. Pengaduan menyangkut kinerja dari kantor-kantor di lingkungan

Departemen Keuangan; atau

2. Pengaduan menyangkut hal-hal lain yang tidak "material", maka penanganan terhadap pengaduan ini dapat dilakukan oleh APIP.

Dalam setiap kegiatan atau pekerjaan yang melibatkan banyak orang kemungkinan terjadinya kesalahpahaman, salah pengertian, miskomunikasi, dan ketidakakuratan informasi antar pelaku, amatlah tinggi. Hal-hal ini mudah mengundang terjadinya kekecewaan antar pihak-pihak tersebut. Beberapa di antara kekecewaan tersebut akan didiamkan dan ditelan oleh pihak yang kecewa dengan berbagai alasan. Beberepa kekecewaan yang lain akan ditumpahkan dalam bentuk protes. Jika tidak ditangani dengan benar, protes-protes semacam ini bisa menimbulkan gejolak dan mengganggu kelancaran pekerjaan. Penanganan pengaduan yang dimaksudkan dalam naskah ini adalah sistem, mekanisme, dan prosedur mengelola keluhan- keluhan atau protes-protes yang mungkin muncul dari berbagai pihak secara terstruktur sehingga tidak menimbulkan gejolak dan mengganggu kelancaran pekerjaan maupun kinerja instansi yang bersangkutan. Tujuan umum penanganan pengaduan adalah menyediakan sistem, prosedur, dan mekanisme yang memungkinkan segala keluhan ataupun protes dari semua pihak dapat terkelola dengan baik sehingga tidak menimbulkan gejolak dan mengganggu kelancaran jalannya kegiatan suatu institusi pemerintah.

Pelayanan merupakan salah satu ujung tombak dari upaya pemuasan pelanggan dan sudah merupakan keharusan yang wajib dipotimalisasikan baik oleh individu maupun organisasi, karena dar bentuk pelayanan yang diberikan tercermin kualitas individu atau organisasi yang memberikan pelayanan. Istilah pelayanan dalam bahasa Inggris adalah "service". Menurut H.A.S. Moenir pelayanan sebagai kegiatan yang dilakukan oleh seseorang atau sekelompok orang dengan landasan tertentu dimana tingkat pemuasannya hanya dapat dirasakan oleh orang yang melayani atau dilayani, tergantung kepada kemampuan penyedia jasa dalam memenuhi harapan pengguna. ${ }^{10}$

Pelayanan pada hakikatnya adalah serangkaian kegiatan, karena itu proses pelayanan berlangsung secara rutin dan berkesinambungan, meliputi seluruh kehidupan organisasi dalam masyarakat. Proses yang dimaksudkan dilakukan sehubungan dengan saling memenuhi kebutuhan antara penerima dan pemberi pelayanan. H.A.S. Moenir menyatakan bahwa proses pemenuhan kebutuhan melalui aktivitas orang lain yang langsung inilah yang dinamakan pelayanan. ${ }^{11}$ Jadi dapat dikatakan pelayanan adalah kegiatan yang bertujuan untuk membantu menyiapkan atau mengurus apa yang diperlukan orang lain. 
Menurut Gumehsoson, pelayanan adalah sesuatu yang dapat diperjualbelikan dan bahkan tidak dapat dihilangkan. ${ }^{12}$ Pelayanan umum adalah segala bentuk kegiatan pelayanan umum yang dilaksanakan oleh instansi pemerintah di Pusat, di Daerah dan di lingkungan Badan Usaha Milik Negara ataupun Badan Usaha Milik Daerah, dalam bentuk barang dan jasa, baik dalam rangka pelaksanaan ketentuan peraturan perundangan (Surat Keputusan Menteri Penerangan No. 81/1993 tentang Pedoman Tatalaksana Pelayanan Umum) maupun dalam proses interaksi sosial masyarakat luas. Berarti pelayanan umum dapat diartikan memproses pelayanan kepada masyarakat/ customer, baik berupa barang atau jasa melalui tahapan, prosedur, persyaratan-persyaratan, waktu dan pembiayaan yang dilakukan secara transparan untuk mencapai kepuasan sebagaimana visi yang telah ditetapkan dalam organisasi.

Berkaitan dalam hal kualitas pelayanan publik, maka kemampuan aparat sangat berperan penting dalam hal ikut menentukan kualitas pelayanan publik tersebut. Untuk itu indikatorindikator dalam kemampuan aparat tingkat pendidikan aparat, kemampuan penyelesaian pekerjaan sesuai jadwal, kemampuan melakukan kerjasama, kemampuan menyesuaikan diri terhadap perubahan organisasi, kemampuan dalam menyusun rencana kegiatan, kecepatan dalam melaksanakan tugas, tingkat kreativitas mencari tata kerja yang terbaik, tingkat kemampuan dalam pertanggungjawaban kepada atasan dan tingkat keikutsertaan dalam pelatihan/ kursus yang berhubungan dengan bidang tugasnya. Selain itu, Zeithaml dan Valarie A mengatakan bahwa ada 4 (empat) jurang pemisah yang menjadi kendala dalam pelayanan publik, yaitu sebagai berikut :

1. Tidak tahu apa yang sebenarnya diharapkan oleh masyarakat;

2. Pemberian ukuran yang salah dalam pelayanan masyarakat;

3. Keliru penampilan diri dalam pelayanan publik itu sendiri;

4. Ketika membuat perjanjian terlalu berlebihan atau pengobralan. ${ }^{13}$

Dalam rangka meningkatkan pelayanan publik melalui aparatur dalam memberikan pelayanan publik setidaknya para pelayan harus mengetahui kebutuhan yang akan dilayani, menerapkan persyaratan menajemen untuk mendukung penampilan (kinerja) dan Memantau dan mengukur kinerja.

Konsep Perpolisian Masyarakat melalui Surat Keputusan Kapolri No. Pol: Skep/737/X/2005 tanggal 13 Oktober 2005 tentang Kebijakan dan Strategi Penerapan Model Perpolisian Masyarakat dalam penyelenggaraan tugas Polri dan turunannya berupa Surat Keputusan Kapolri No. Pol: Skep/433/VII/2006 tanggal 01 Juli 2006 tentang Panduan Pembentukan dan Operasionalisasi 
Perpolisian Masyarakat, secara sistematik akan menjadi angan-angan kosong belaka jika tidak disertai komitmen dan kerja keras untuk merealisasikannya. Karena itu diharapkan seluruh anggota Polres mulai tingkat bawah sampai pucuk pimpinan bisa menerapkannya dalam pelaksanaan tugas dan kehidupan sehari-hari, walaupun tidak segampang membalikkan telapak tangan.

Sentra Pelayanan Kepolisian Terpadu (SPKT) merupakan organisasi dengan tampilan fungsi pelayanan kepolisian bersifat umum dan khusus yang dilaksanakan secara terpadu, dalam bentuk penerimaan dan penanganan laporan atau pengaduan, pemberian bantuan atau pertolongan dan pelayanan surat keterangan, serta menyajikan informasi yang berkaitan dengan kepentingan tugas kepolisian. SPKT merupakan ujung tombak pelayanan kepolisian dalam memberikan pelayanan kepada masyarakat, oleh karena itu peningkatan pelayanan di SPKT sangatlah penting. Sesuai dengan Peraturan Kepala Kepolisian Negara Republik Indonesia Nomor 23 Tahun 2010 tentang Susunan Organisasi dan Tata Kerja pada tingkat Kepolisian Sektor, dalam Pasal 10 huruf a menerangkan bahwa SPKT bertugas :

1. Memberikan pelayanan Kepolisian secara terpadu kepada masyarakat dalam bentuk penerimaan dan penanganan laporan atau pengaduan, pemberian bantuan atau pertolongan dan pelayanan surat keterangan;

2. Menyajikan informasi yang berkaitan dengan kepentingan tugas kepolisian guna dapat diakses sesuai dengan ketentuan peraturan perundang-undangan.

\footnotetext{
${ }^{13}$ J. Supranto. (2001). Pengukuran Tingkat Kepuasan Pelanggan untuk Menaikkan
} 
Dalam pelaksanaan tugas sebagaimana dimaksud pada ayat (2), SPKT menyelenggarakan fungsi :

1. Pelayanan kepolisian kepada masyarakat secara terpadu, antara lain Laporan Polisi (LP), Surat Tanda Terima Laporan Polisi (STTPLP), Surat Pemberitahuan Perkembangan Hasil Penyidikan (SP2HP), Surat Keterangan Tanda Lapor Kehilangan (SKTLK), Surat Keterangan Catatan Kepolisian (SKCK), Surat Tanda Terima Pemberitahuan (STTP), Surat Keterangan Lapor Diri (SKLD), Surat IZIN Keramaian, Surat Rekomendasi Izin Usaha Jasa Pengamatan, Surat Izin Mengemudi (SIM), dan Surat Tanda Nomor Kendaraan Bermotor (STNK);

2. Pengkoordinasian dan pemberian bantuan serta pertolongan, antara lain Penanganan tempat Kejadian Perkara (TKP) meliputi Tindakan Pertama di TKP (TPTKP) dan pengolahan TKP, Turjawali, dan pengamanan;

3. Pelayanan masyarakat anatar lain melalui telepon, pesan singkat, faksimili, internet (jejaring sosial), dan surat;

4. Penyajian informasi umum yang berkaitan dengan kepentingan masyarakat sesuai dengan ketentuan peraturan perundang- undangan;dan

5. Penyiapan registrasi pelaporan, penyusunan, dan penyampaian laporan harian kepada Kapolda melalui Roops.

Sentra Pelayanan Kepolisian Terpadu (SPKT) terdiri dari Urusan Perencanaan dan Administrasi (Urrenmin) dan Kepala Siaga SPKT (Ka Siaga SPKT). Ka Siaga SPKT terdiri dari Ka Siaga SPKT I, II, dan III. Dalam pelaksanaan tugasnya, Ka Siaga SPKT dibantu Oleh :

1. Perwira Pelayanan Masyarakat (Payanmas), yang bertugas memproses pelayanan penerimaan dan penanganan laporan atau pengaduan masyarakat, serta pemberian bantuan dan pertolongan kepolisian;

2. Perwira Administrasi (Pamin), yang bertugas menyelenggarakan pengadministrasian umum kegiatan siaga SPKT dan pelayanan surat keterangan kepolisian; dan

3. Piket Fungsi dari masing-masing fungsi operasional yang bertugas membantu Ka Siaga dalam menindaklanjuti seluruh kegiatan pelayanan dan pemberian bantuan pertolongan kepolisian kepada masyarakat.

4. Konsep nilai dan norma Kepolisian menyangkut Pelayanan Publik menjadi sangat penting karena nilai dan norma menjadi pegangan di dalam pilihan tindakan dan dasar moral untuk dasar pembenaran dan evaluasi prilaku moral. Kemampuan untuk menciptakan nilai-nilai melalui analisa, pemahaman, dan penerapan merupakan pintu masuk perbaikan pelayanan publik. Dengan demikian pengaplikasian tanggungjawab menjadi bentuk pemberdayaan publik, terutama untuk mereka yang langsung berhadapan 
dengan masyarakat. Adanya aturan dan pengawasan dapat meningkatkan rasa tanggungjawab dan mendorong orientasi hasil kerja. Proses peningkatan rasa tanggungjawab ini diharapkan akan membuat pelayanan publik lebih memperhitungkan dan memperhatikan pengembangan praktik pelayanan publik, pentingnya penambahan dan pengalaman, perubahan terus- menerus kondisi kerja dan organisasi. Pelayanan publik yang profesional membutuhkan kompetensi teknik, kompetensi ini membuat efektif dan efisien yang mengarah ke nilai. Dalam pelayanan publik, lemahnya perilaku etis atau lemahnya perilaku tidak sesuai dengan norma dapat melemahkan institusi kepolisian dan berefek pada orang banyak atau masyarakat. Padahal hakikat utama pelaksanaan kekuasaan terletak pada tanggungjawab moral.

Sistem nilai terlihat pada etika profesi kepolisian yaitu acuan oknum polisi dalam bertindak, mengetahui tindakan yang dilatar belakangi oleh norma sebagai awal dalam mengambil langkah maupun keputusan yang bijak tanpa pengecualian. Peraturan Kepala Kepolisian Negara Republik Indonesia nomor 14 tahun 2001 mengenai Kode Etik Profesi Kepolisian menerangkan etika profesi polri adalah kristalisasi nilai-nilai tribrata dan catur prasetya yang dilandasi dan dijiwai oleh pancasila serta mencerminkan jati diri setiap anggota polri dalam wujud komitmen moral yang meliputi etika kenegaraan, kelembagaan dan kepribadian.

\section{Kesimpulan}

Peran penting sumberdaya manusia Polres Gresik dalam meningkatkan pelayanan publik sangatlah penting guna meningkatkan kualitas yang sesuai dengan yang diharapkan masyarakat serta dilaksanakan dalam suatu rangkaian terpadu yang bersifat sederhana, terbuka, lancar, tepat, lengkap, wajar, dan terjangkau sesuai asas-asas pelayanan publik. Sehingga dapat mewujudkan penyelenggaraan negara yang bersih dan bebas dari korupsi, kolusi dan nepotisme serta meningkatkan pelayanan Kepolisian Negara Republik Indonesia yang profesional, modern dan terpercaya dibutuhkan peran serta masyarakat dalam bentuk penyampaian dan pengaduan sesuai dengan prinsip keterbukaan untuk ditangani secara baik, cepat, tepat dan dapat dipertanggungjawabkan. Oleh sebab itu diharapkan pihak Polres Gresik dalam memberikan layanan publik berdasarkan Asas Keprofesionalan, Asas Persamaan Perlakuan, Asas Keterbukaan, Asas Akuntabilitas dan Asas Kecepatan, Kemudahan, dan Keterjangkauan serta Prinsip Obyektivitas, Koordinasi, Efektivitas dan Efisiensi dan Kehati- hatian. 


\section{Bibliography}

Ali, Achmad. (2012). Menguak Teori Hukum (Legal Theory) dan Teori

Peradilan Republik Indonesia. Jakarta: Sinar Grafika, p.28. Daerah Jawa Timur tahun 2018.

Grand Strategi Polri 2005-2025.

J. Supranto. (2001). Pengukuran Tingkat Kepuasan Pelanggan untuk

Menaikkan Pangsa Pasar.Jakarta: Rineka Cipta.p.3.

Karnavian, Muhammad Tito. (2017). Democratic Policing. Jakarta.

Kusumaatmadja, Mochtar dan Sidharta, Bernard Arief.( 2004). Laporan Tahunan Bidang

Profesi dan Pengamanan Kepolisian Lembaga Administrasi Negara.Op.Cit.

Moenir, H.A.S. (2002). Manajemen Pelayanan Umum di

Indonesia.Jakarta: Bumi Aksara.p.26-27.

Pengantar Ilmu Hukum. Buku I. Bandung: Alumni.p.5.

Satjipto Rahardjo.( 2012). Ilmu Hukum. Bandung: Citra Aditya Bakti.p.25.

Simanjuntak dan Mukhlis. (2012). Dimensi Ekonomi Perpajakan dalam Membangun Ekonomi, Bogor: Penerbit RAS.p.3. Sudaryanto, Agus. (2015).

Pengantar Ilmu Hukum. Malang: Setara

Press. p. 89-99.0

Yudiswan, Adex. (2016). Gerakan Antisipasi Kejahatan dan Pemecahan Masalah Masyarakat Desa (Gajah Mada).Gresik: Rayhan Intermedia. 